\title{
Relationship Between Function-Form in The Expression of Architectural Creation
}

\author{
Rudy Trisno ${ }^{1}$ iD \\ Tarumanagara University, Indonesia \\ Fermanto Lianto ${ }^{2}$ \\ Tarumanagara University, Indonesia
}

\begin{abstract}
In the Postmodern era there are diverse forms of architecture, which is also related to. structural and material technology that is developing so rapidly. The method used is the analysis of architectural theories to find the relationship between Function-Form, whether: 1) The concept of Form follows Function; 2) The concept of Function follows Form; 3) The concept of Form and Function runs together. The relation between the concept of Function and Form will result in the meaning of the architectural work itself. The conclusion is: in architectural design there is no exact rule whether the Function must follow the Form, or Form must follow the Function, or Function and Form run side by side, but the relationships between Function and Form merge into a single method towards the expression of architectural Form, so that this Function-Form relationship will be interpreted by the observer towards the expression of the architectural creation itself. The findings in this study are to give architectural designers freedom regarding the relationship between Function-Form. However, the most important thing from this relationship is that the meaning must be reflected in the expression of the form that corresponds to the relationship to be achieved. The benefit of this research is that architectural students can know more deeply the relationship between the Function-Form that will be used in the design, and also for architect practitioners in designing the building.
\end{abstract}

\section{Keywords \\ Function-Form relationships; Form expression; Building function; Expression of architectural creation; Meaning of architecture}

\section{Introduction}

Based on teaching experience in architecture design lectures at Tarumanagara University, problems often occur regarding Function-Form. In designing architectural buildings, whether the designed building must follow the Function, or follow the Form, these problems make a very interesting phenomenon to study, because there are contradictions between Function-Form in architectural design. whether the architectural design begins with the Function following the Form or Form following the Function, both phenomena will lead to a very different meaning (Hendrix, 2013: 199).

Problems of Function-Form are very interesting to be discussed in this study, because this process continues to run in accordance with the progress of structural technology and the technology of building materials that develop in accordance with the era. The advancement of modern technology such as structural technology and the discovery of new material technology is what expresses the shape of the building so that it reflects the spirit of the age (Jodidio, 2005).

The discussion of the Function-Form associated with architecture has occurred for a long time, beginning with; 1) $4^{\text {th }}-7^{\text {th }}$ century Roman style; 2) $7^{\text {th }}-12^{\text {th }}$ century Romanic style; 3$) 12^{\text {th }}-15^{\text {th }}$ century Gothic style; 4) $15^{\text {th }}-19^{\text {th }}$ century Renaissance style, Baroque style, and Neo Gothic style; 5) $19^{\text {th }}$. $20^{\text {th }}$ century, the Modern style to the Postmodern style. Since this problem is often debated, this issue will be very interesting to study more deeply in its relation between Function-Form.

\footnotetext{
1,2Department of Architecture, Tarumanagara University, Jakarta 11440, Indonesia
}

Corresponding author:

Fermanto Lianto, Department of Architecture, Tarumanagara University, $1^{\text {st }}$ S. Parman, Jakarta 11440 , Indonesia

Email: fermantol@ft.untar.ac.id 
The benefits of this research are for architectural students to know more about when the FunctionForm will be used in design and for architect practitioners in designing buildings.

\section{Material and Methods}

Form follows function was pioneered by architect Louis Sullivan, who said, the shape of the building should follow its Function to produce creative architectural creation, not only Form follows Function, but also includes building structures following Function (Sullivan, 1947: 208).

Architects who have different views about relationship between Function and Form are as follows; the architect Le Corbusier said that the Form of architecture is the product of the mind which is the highest feeling of art, mathematical principles, and also a balanced proportion of the whole (Behne, 1996: 134), so the Form called by Corbusier is a Form that is more important than Function, because Form is expressions of art, mathematical principles, and also of balanced proportions with the whole.

Eisenman said that the basic Form of modern architecture is that not all Forms will depend entirely on the needs of the Function (Eisenman, 2006: 27). So, Function doesn't just follow Form, but there are certain things not to be followed.

In www.azquotes.com; 1) Frank L Wright said that the Function which always follows Form is a misunderstanding, Function and Form are one entity, this unity is a spiritual unity (Azquotes, 2018: quote/321191); 2) Antonio Gaudi said Forms are not required to follow Functions (Azquotes, 2018: quote/1211855); 3) Carl Magnusson says a good design doesn't just follow Function. But it can also function for cultural content by incorporating local cultural content (Azquotes, 2018: quote/822420).

Robert Venturi in the book of Complexity and Contradiction Chapter 6 (1966) says that Form reflects human identity, which can be interpreted that the Form is created based on the architect's creativity in expressing its form (Venturi, 1966).

In the postmodern era of architectural creation, it is assumed that the relationship of Function following Form has begun to be abandoned due to the rapid development of structural and building material technology. This can be seen in the creation of Renzo Piano in the Pompidou Center building in 1979, Daniel Libeskind's creation on the 2006 Denver Art museum building, Frank Gehry's creation on the Guggenheim museum in Bilbao in 1996, the building of the 2003 Walt Disney Concert Hall, Zaha Hadid's creation on the 1993 Vitra Fire Station building, and Rooftop Remodelling Project building in 1988 (Hendrix, 2013: 14-15).

Bernard Tschumi says there is an arbitrary relationship between Function and Form, or also the relationship between functional roles with metaphysics used by architecture, to be manifested in the language of architecture, so it is revealed between signed and signified. In architectural language, it is done by manipulating the grammar and syntax of the sign architecture, so that Form can only be transferred to other Form, and not to Function (Tschumi, 1994: 36).

Rob Krier (1988) in his architectural composition book writes, Function, Construction and Form are the same values for designing architecture, there are no different priorities (Krier, 1988: 10). Architecture must focus on these three goals and merge into a single method, all of which yield one conclusion in the concept of architecture (Scoot, 1914: 1). Form is obtained from three elements of floors, walls and roofs (Thiis-Evensen, 1987: 430448). If these elements are not useful then there is no plausible function of them, (Taut, 1929: 135).

Salura (2015) in the Function-Form-Meaning architecture, says that function is context while form is structure, and the Meaning is appearance. These Function-Form-Meaning do a continuous rotation and never stagnate (Salura, 2015: 83).

Norberg Schulz (1963), N. L. Park (1968) and Colin St John Wilson (1992) explain that there are four categories of architectural concepts that might be useful to consider, namely; Construction, Function, Form, and Meaning, but the architectural concept is only taken from the selected category. Schulz developed the idea of the Function-Form-Meaning architectural concept, with that meaning; 1) Function is building task, identified with pragmatics and used as a psychological effect; 2) Form identified by syntactic that refer to formal relationships to sign with each other; 3 ) The Meaning in question is the meaning of the sign equal to architecture in general. Then Schulz continued the development of Function-Form-Meaning to be even simpler with the following description; 1) Function is 
social; 2) Form is physical building; 3) Meaning is cultural (Schulz, 1963; Park, 1968; Colin, 1992).

Capon (1999) classifies the primary category for architecture that is Function-Form-Meaning, and second category is Context-Modality-Will. Function-Form-Meaning is described as follows; 1) Functions are Function, Uses, Suggestions, Tasks, Objectives, Causes, Effects, Strengths, Physics, Energy, Actions, Reactions, Needs, Utilities, Pragmatic, Exercise, Doing, Motion, Activity, Behaviour, Life, Social, Physical, Economic, Comfort, Kindness, Ethics, Morality; 2) Forms are Form, Mass, Space, Shape, Articulation, Disjunction, Contact, Unity, Being, Perception, Senses, Feelings, Beauty, Aesthetics, Harmony, Proportion, Quantity, Geometry, Mathematics, Physics, Structure, Syntax; 3) Meanings are Meaning, Concepts, Ideas, Semantics, Symbols, Types, Species, Inherence, Quality, Style, Decency, Associations, Knowledge, Logic, Intellect, Representation, Equality, Impersonation, Truth, Integrity, Principles, Law, Theory, History , Tradition, Culture (Capon, 1999: 12, 332-333).

In the postmodern era, besides Function and Form, there are additional meanings that are very influential in designing architectural expressions. This meaning is derived from the relation between Function-Form, the meaning in the Postmodern era greatly influences the expression of architectural creation, so the observer will interpret whether the expression is in accordance with the architectural concept.

So based on the above description of the theory, the research method was developed to find the relationship between Function-Form namely; 1) The concept of Form follows Function; 2) Concept of Function follows Form; 3) The concept of Form and Function runs together. The relation between the concept of Function and Form will result in the Meaning of the architectural work itself.

\section{Results and Discussion}

Based on the analysis method of Function-Form, three groups are categorized with the following description; 1) The concept of Form follows Function; 2) Concept of Function follows Form; 3) The concept of Form and Function runs together. Then based on this method, the concept of buildings that reflect the relationship between the concept of Function and Form will be analysed and will be associated with the Meaning of these three concepts, in accordance with what the architect wants to express.

\section{Concept of Form Follows Function}

In the analysis of the concept of Form follows the Function, the example taken to examine this case is the Notredame de Paris Church building and Jean Marie Tjibaou Cultural Centre.

\section{Notredame Catholic Church}

The Notredame Catholic Church was built with the Gothic concept of 1163-1330 in Paris France, by architect Maurice de Sully with stone material (Figure 1). This Catholic church building is designed based on its liturgical Function so that this building is in accordance with the ideogram and the God symbol so that the expression of sacredness is reflected both in its interior and exterior (Trisno \& Lianto, 2018).

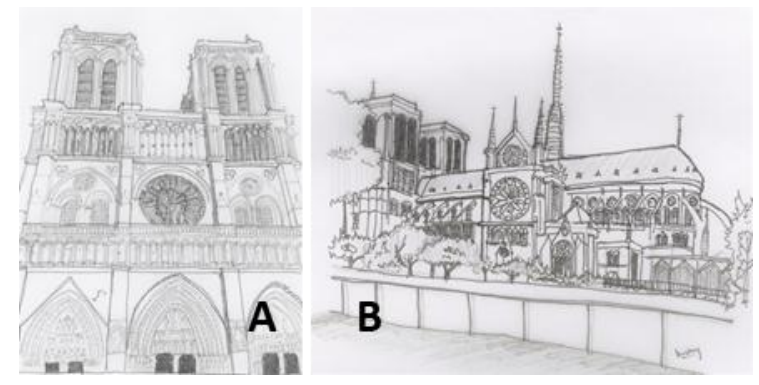

Figure 1. (A) Front Elevation; (B) Side Elevation of Notredame Church

\section{Jean-Marie Tjibaou Cultural Centre}

The Jean-Marie Tjibaou Cultural Center was built with the 1989 High Tech concept in Noumea, New Caledonia, by architect Renzo Piano with wood and stainless material (Figure 2). This building is based on the Function in relation to ethics that reflects the morality of the behavior and activities of the local hero Jean-Marie Tjibaou who fought for independence in his area. Function according to Capon's approach (1999) is also ethics, morality, behaviour and activities, so Renzo Piano's work on the Jean-Marie Tjibaou Cultural Center begins with a Function that elevates JeanMaree Tjibaou's ethics, morality, behaviour and activities, so that the form expression follows its function, regarding to local culture and architecture. 

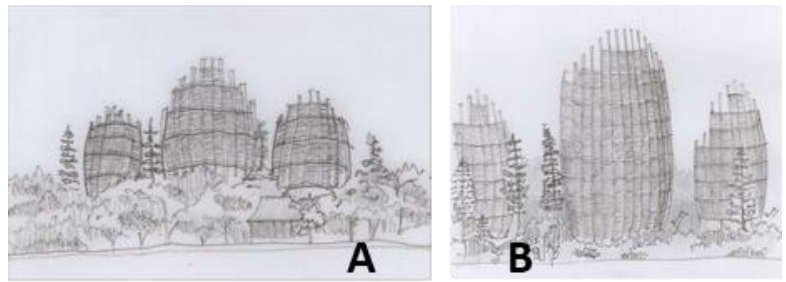

Figure 2. (A) Building; (B) Building details of JeanMarie Tjibaou Cultural Centre

\section{Concept of Function Follows Form}

Example of buildings taken for Function follows Form are building Water Temples and the Disney Concert Hall.

\section{Water Temple Honpuku-Ji}

Honpuku-Ji Water Temple was built with the concept of geometric forms 1990-1991 at Awaji, Hyogo Japan, by architect Tadao Ando with material concrete exposed (Figure 3). This building begins with a geometric Form of a circle symbolizing Lotus flowers, the concept of Lotus flower is a flower that can grow in a dirty area full of mud and this flower is also useful for humans because the fruit can be eaten. The Function of the building as a place of worship is under the pool of water with a red climax, because the birth position of Siddhartha Gautama was in India, which, on a world map lies in the west of Japan, west symbolizes the sunset position, where sunset is symbolized in red, so the climax of the water temple building has a red nuance. Then it can be said that the Function of this building follows the geometric Form of the circle.

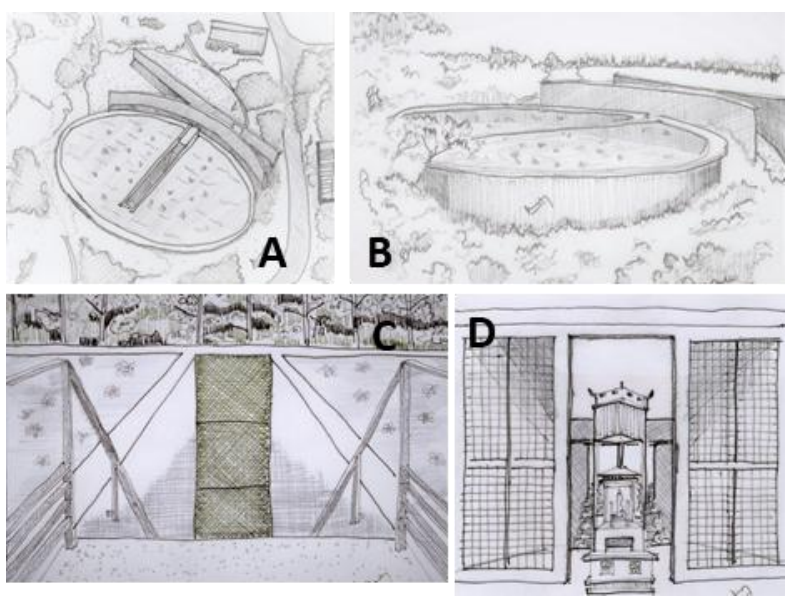

Figure 3. (A) Situation; (B) Building; (C) Entrance; (D) Worship Place of Water Temple

\section{Disney Concert Hall}

The Disney Concert Hall was built with the 2003 Deconstructivist concept at Los Angles, California, USA, by architect Frank Gehry with stainless steel and stone materials (Figure 4). This building uses the Deconstructivist concept which means the Form factor is the main factor. This can be seen from the use of the material structure of Stainless steel which is very dominant in the expression of buildings, while the building Function is for a concert hall, so in this building the Function follows the Form.

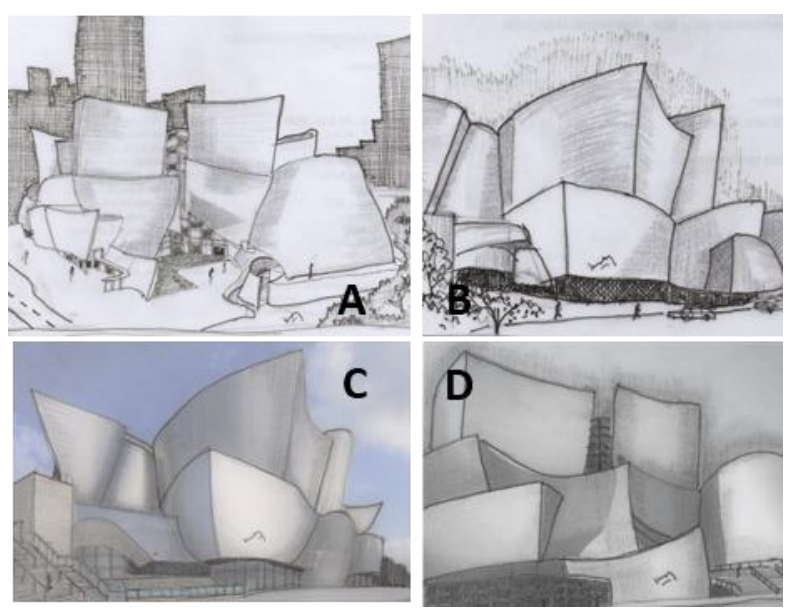

Figure 4. (A) The Structure of Stainless Steel Affects the Expression of Buildings; (B-D) Direction of Concert Hall from 3 Different Points

\section{The concept of Form and Function runs together}

The concept of Form and Function is just as strong in the sense that these two concepts stand alone as strong, so that the expression of the Form has the same dominant of Function and Form. The building under study of this concept was Valleaceron Chapel, Spain and Beijing National Stadium (Birds Nest), China.

\section{Valleacevon Chapel}

Valleaceron Chapel was built with the concept of folding and unfolding in 2000 in Spain, by architects Juan Carlos Osinaga and Sol Madridejos Fernandez with concrete material exposed (Figure 5 ). The shape of a rectangular geometric building with the concept of folding and unfolding so that the expression of the expected Form such as paper folds and visual expression Form of the building look as if they run together. The function of the building is used for the ritual procession; the sanctuary is in the highest position with a 
monumental scale. Inserted light in Sanctuary adds a sacred impression in the building. So that the space in this building is in accordance with the ideogram (Trisno \& Lianto, 2018).

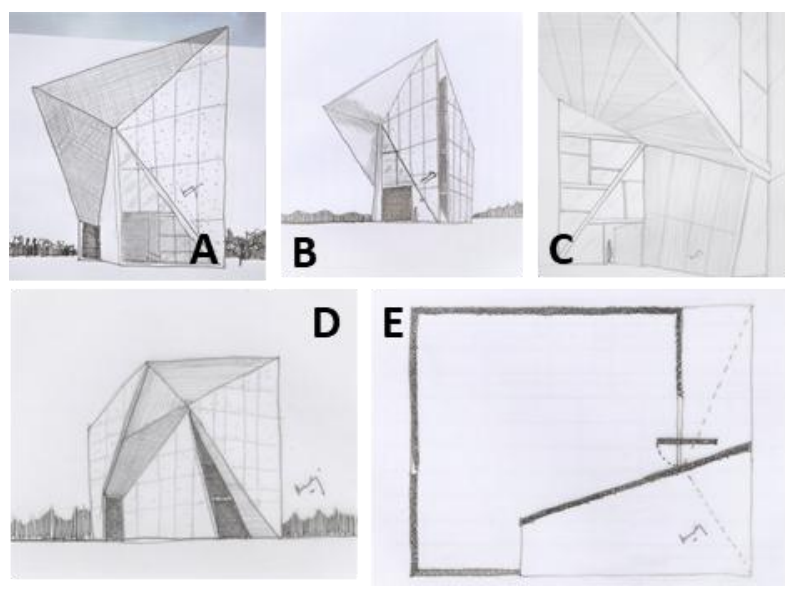

Figure 5. (A-E) Valleacevon Chapel

The main door can be seen in Figure 5A and 5B, Figure $5 \mathrm{C}$ is the position of the main door seen from inside the building, in Figure 5D the door is seen from the rear position of the building, which is the highest position of the building because of the Sanctuary's location, and in the floor plan the position $\mathrm{E}$ is the position of the most sacred sanctuary.

\section{Beijing National Stadium}

Beijing National Stadium (Bird's Nest) was built with the 2008 Bowl and Birds Nest concept in Beijing, China, by architects Herzog and De Meuron with steel, concrete and resin materials (Figure 6). The concept of this building is reflected in the relationship between Function and Form that each looks independent and running together because the Form uses the structure concept of Birds Nest, while the function uses the concept of a Bowl that can accommodate 91,000 spectators, so that the building has no different priorities and also the building expression of Function and Form is cantered and melts into a single method, all of which produce one conclusion in the concept of architectural design.

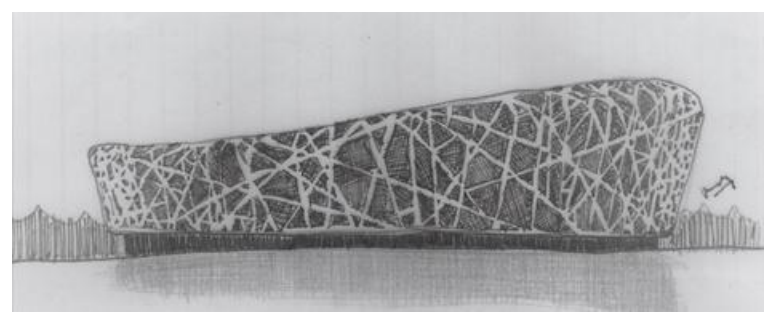

Figure 6. Beijing National Stadium (Birds Nest)

\section{Conclusions}

Based on the description of Function-Form, there is a relationship between Function-Form so that this relationship gives rise to the Meaning of the expression of the architectural Form. Thus, it can be said that the Function-Form relationship can occur if the relationships are those of Form follows Function, can also the Function follows Form or can also Function and Form each runs together, but the relations between these Function-Form merge into a single method towards the expression of the Form of architecture, so that relationships between these Function-Form will be interpreted by the observer towards the expression of the architectural creation itself.

The findings in this study are to give architectural designers freedom of relation between FunctionForm, but the most important thing is the Meaning must be reflected by the expression of the Form that is designed

\section{References}

Azquotes. (2018). azquotes.com. Retrieved October 2, 2018, from https://www.azquotes.com.

Behne, A. (1996). The Modern Functional Building. Santa Monica: The Getty Research Institute for the History of Art and the Humanities.

Capon, D. S. (1999). Architecture Theory Lecture Volume Two Le Corbusier's Legacy. England: John Wiley \& Sons Ltd.

Colin, S. J. (1992). Architectural Reflections. Oxford: Butterworth Architecture.

Eisenman, P. (2006). The Formal Basis of Modern Architecture. Baden: Lars Muller.

Hendrix, J. S. (2013). The Contradiction Between Form and Function in Architecture. London: Routledge.

Jodidio, P. (2005). Architecture Now. Koln: Taschen.

Krier, R. (1988). Architectural Composition. London: Papadakis.

Park, N. (1968). The Language of Architecture. The Hague: Mouton.

Salura, P. (2015). Arsitektur yang membodohkan. Jakarta: Gakushudo.

Schulz, N. (1963). Intention in Architecture. London: Allen \& Unwin.

Scoot, G. (1914). The Architecture of Humanisme: A Study in History of Taste. London: Constable \& Co.

Sullivan, L. (1947). Kindergarten Chats and Other Writing. London: Routledge.

Taut, B. (1929). Modern Architecture. London: The Studio Ltd. 
Thiis-Evensen, T. (1987). Archetypes in Architecture. Tschumi, B. (1994). Architecture and Disjunction. MA: Oslo: Norwegian University Press. The MIT Press.

Trisno, R., \& Lianto, F. (2018). Catholic church is the divinity symbol with case study of Santa Venturi, R. (1966). Complexity and Contradiction. Theresia church in Jakarta, Indonesia. New York: The Museum of Modern Art.

International Journal of Engineering and Technology (IJET), Vol. 10 (3) Jun-Jul 2018, 865-872. 